\title{
Smoking Habits Among Assiut University Students: Prevalence and Associated Risk Factors
}

\author{
HALA H. ABOU-FADDAN, M.D. and SABRA M. AHMED, M.D. \\ The Department of Public Health, Faculty of Medicine, Assiut University, Assiut, Egypt
}

\begin{abstract}
Aim of Study: To study the prevalence and socio-demographic associated factors of smoking among Assiut university students.

Patients and Methods: A cross-sectional study design was carried out. Data were collected by using anonymous selfadministered questionnaire. The questionnaire covered the socio-demographic characteristics of the students in addition to questions about smoking history of students and their family members and friends. Bivariate and multivariate logistic regression analyses were performed to assess correlates of tobacco use.
\end{abstract}

Results: Among 1095 students participated in the study $18.9 \%$ have ever used cigarette in their life time and $17.1 \%$ are using tobacco currently. Smoking was significantly related to male gender $(\mathrm{OR}=13.2)$, students with drug abuse (OR $=12.1)$, smoker friend $(\mathrm{OR}=11.5)$, smoker father and/or brother $(\mathrm{OR}=10.8)$, pocket money $>150$ pounds per month $(\mathrm{OR}=4.5)$ and students who liver away from their families $(\mathrm{OR}=3.7)$.

Conclusion and Recommendations: Smoking is prevalent among Assiut University Students. An integrated smoking prevention program in the university students was recommended.

Key Words: Smoking prevalence - Correlates - Assiut University students.

\section{Introduction}

TOBACCO use is considered nowadays the single greatest preventable cause of death in the world. Smoking kills about half of the people who are using it. Quite one quarter of adult population worldwide ( $>1$ billion people), are currently using tobacco. Smoking currently kills about 5.2 million individuals all over the world every year, a number which is expected to reach more than eight million per year by the year 2030 [1]. Most of these deaths are expected to occur in developing countries if no change in the current trend occurred [2] .

Correspondence to: Dr. Hala H. Abou-Faddan, The Department of Public Health, Faculty of Medicine, Assiut University, Assiut, Egypt
Smoking in Egypt constitutes a public health problem. One fifth (19.7\%) of the Egyptian population are currently using some form of tobacco product. Men are more likely (38.1\%) to use tobacco than women $(0.6 \%)$ according to global adult tobacco survey (GATS) [3]

All countries everywhere in the globe attempt to stimulate and start efforts to face smoking, particularly among youth [4].

University students are at higher risk of smoking since they are more likely to accept cigarettes smoking and close association with smoking peers. Simultaneously, they face added social, emotional and educational challenges when they enter the university $[\mathbf{5 , 6 ]}$.

Researchers reported that university students believe that they can easily stop smoking. They forgot the addictive nature of nicotine and the long term health hazards of smoking [7].

To our knowledge, there is lack of recent studies about prevalence and determinants of smoking among Assiut university students. Therefore, this study was conducted to estimate the prevalence and risk factors of smoking among Assiut University students.

General objective: To promote proper health behaviors among Assiut University students including smoking cessation.

\section{Specific objectives:}

1 - To estimate the prevalence of smoking among Assiut University students.

2- To study the socio-demographic and familial factors associated with smoking among Assiut University students. 


\section{Subjects and Methods}

Study setting: The study was done in Assiut University which includes 18 faculties.

Target population: Under graduate students of Assiut University.

Study design: A cross-sectional study design.

Sample size: Sample size was computed utilizing EPI INFO version 3.5.1 (2008). The sample size calculation depended on an estimated prevalence of smoking of $19.7 \%$ (according to global adult tobacco survey in Egypt, 2009) [5]. With a power of $80 \%$ and confidence level of $95 \%$ and a design effect of 1.5. The sample required for the study was 1024 students. The sample was expanded to 1095 to compensate for dropouts.

Sampling technique: A stratified proportionate random sampling technique was utilized. Faculties were grouped into two strata; practical and theoretical and two faculties were selected randomly from each stratum. Finally, a cluster sample (practical sections or small classes) was selected randomly from each selected faculty. The clusters were choosing according to the proportionate allocation of students in each stratum. The sample was allocated proportionately between the two strata as shown in Table (1).

Table (1): Distribution of students under study according to academic year and type of college.

\begin{tabular}{ll}
\hline Academic year & Frequency \\
\hline Academic year: & \\
- 1 st year & $266(24.3)$ \\
- 2nd year & $239(21.8)$ \\
- 3 rd year & $209(19.1)$ \\
- 4th year & $191(17.4)$ \\
- 5 th year & $190(17.3)$ \\
Type of college: & \\
• Practical: & $462(42.3)$ \\
$\quad$ - Faculty of medicine & $231(21.1)$ \\
- Faculty of engineering & $232(21.2)$ \\
- Theoretical: & $630(57.7)$ \\
- Faculty of education & $216(19.7)$ \\
- Faculty of commerce & $415(38.0)$ \\
\hline Total & $1095(100.0)$ \\
\hline
\end{tabular}

Pilot study: For evaluation the clarity of the questions and identifying any logistic problem, the questionnaire was pretested on 15 students from Assiut faculty of medicine; those were not included in study. Necessary modification was carried out before starting final data collection.
Duration of data collection: Data collection was conducted between beginnings of February to end of March, 2017.

Target population: Under-graduate Assiut University students.

Data collection: Data was collected by using anonymous self-administered questionnaire. The researchers distributed the questionnaires to the students. The aim of the study and any students' questions were clarified by the researchers. After filling the questionnaires (which was taking about 15 minutes of time) by the students, they were collected by the researchers. Out of 1150 questionnaires distributed to students, the returned complete questionnaires were 1095 with a response rate of $95 \%$.

The questionnaire used in this study was divided into two modules:

1- The first module included the socio-demographic information about students (age, gender, family residence, education and occupation of the parents, perceived health status, .........etc).

2- The second module was about smoking history of the of the students (whether the student is smoker or not, type of smoking, age at start of smoking, smoking among friends and other family members).

Operational definitions: According to another study [8] the following operational definitions was used:

- Non-smokers are the individual's who never smoked any kind of tobacco throughout their life.

- Current smokers are students who are regular or occasional tobacco smoke at least once per day now.

- Ever smokers include both current and ex-smoking students.

Statistical analysis: SPSS program, version 20 was used for data entry and analysis. Frequencies were reported as percentages; $\mathrm{X}^{2}$-test was used for comparisons between frequency-based data. Continuous variables were compared using two-tailed independent-sample $t$-tests. For all comparisons, the statistical level of significance was set at $p<0.05$. Multivariate logistic regression analysis was carried out for significant variables.

Ethical consideration: Before starting data collection proposal was reviewed and approved via the Ethical Review via the Ethical Review Committee of Assiut Faculty of Medicine. Moreo- 
ver, Permission was taken from dean of the faculties under study. The aim of the study was explained to participants and informed consent was obtained before filling the questionnaire. Confidentiality of the data was kept all over the study.

\section{Results}

Table (2) shows smoking profile of studied students in Assiut university. Ever smoker students constituted 18, 9\%. Cigarette smoking was present among $91.8 \%$ of smokers and water pipe smoking was present among $8.2 \%$ of them. More than half of smokers $(53 \%)$ started smoking before the age of 15 years.

Table (2): Smoking pattern among studied students in Assiut University, 2017.

\begin{tabular}{ll}
\hline Characteristics & Frequency $(\%)$ \\
\hline Smoking: & \\
$\quad$ - Current smokers & $187(17.1)$ \\
$\quad$ - Ever smokers & $207(18.9)$ \\
- Non-smokers & $888(81.1)$ \\
Type of smoking: & \\
- Cigarette smoking & $190(91.8)$ \\
- Water pipe smoking & $17(8.2)$ \\
Number of cigarette smoked $(n=190):$ & \\
- <10/day & $48(25.3)$ \\
- 10-20/day & $98(51.5)$ \\
- >20/day & $44(23.2)$ \\
- Mean \pm SD & $10.2 \pm 3.4$ \\
Age at start of smoking: & \\
- <15 years & $110(53.1)$ \\
- $\geq 15$ years & $97(46.9)$ \\
- Mean \pm SD & $16.2 \pm 2.3$ \\
\hline Total & \\
\hline
\end{tabular}

Table (3) shows the socio-demographic characteristics of studied students. This study included 1095 students, of them one half $(50.6 \%)$ were males, and $54.5 \%$ were from urban areas. The mean age of students was 20.6 years. Regarding education of parents, $15.9 \%$ of fathers were illiterate or only can read and write whereas one half $(50.4 \%)$ of them had university or higher education, one quarter $(25.3 \%)$ of mothers were illiterate or only read and write and $39.4 \%$ had university or higher education. Regarding occupation of parents, 68.1 and $35.1 \%$ of fathers and mothers were employees. Most of students (72.2\%) live with their families. The majority of students (93\%) were single. The perceived health status of the students was excellent or very good in $46 \%$ of them.
Table (3): Socio-demographic characteristics of studied students in Assiut University, 2017.

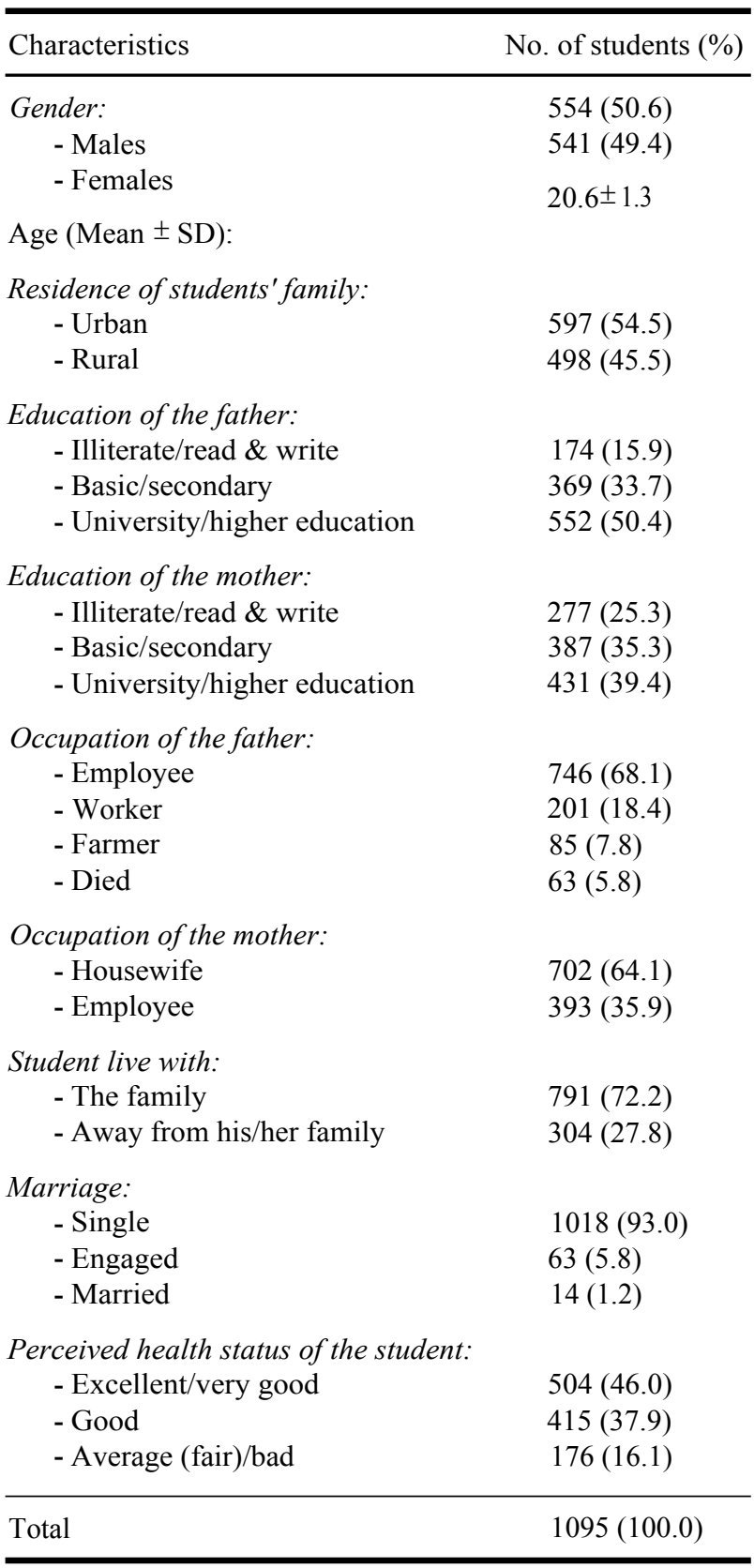

Table (4) shows distribution of smoking among students by socio-demographic characteristics. Male gender had significantly higher prevalence of smoking $(36.8 \%)(p<0.001)$. Students whose fathers had university or higher education had significantly higher prevalence $(21.2 \%)$ of smoking $(p=0.036)$. Students who live away from their families and those with only one parent present had significantly higher smoking prevalence $(26 \%$ and $25.6 \%)(p<0.001$ for each). Also, studying in a theoretical faculty and failed students had significantly higher prevalence of smoking (21.7 and $40.9 \%)(p=0.005$ and $<0.001)$ respectively. 
Table (4): Distribution of smoking among studied students by socio-demographic characteristics, (Assiut University, 2017).

\begin{tabular}{|c|c|c|c|}
\hline Characteristics & Smokers & $\begin{array}{l}\text { Non- } \\
\text { smokers }\end{array}$ & $p$-value \\
\hline \multicolumn{4}{|l|}{ Gender: } \\
\hline - Males & $204(36.8)$ & $350(63.2)$ & \multirow[t]{2}{*}{$<0.001$} \\
\hline - Females & $3(0.6)$ & $538(99.4)$ & \\
\hline Age (Mean \pm SD): & $20.9 \pm 1.2$ & $20.5 \pm 1.3$ & $<0.001$ \\
\hline \multicolumn{4}{|l|}{ Family residence: } \\
\hline - Urban & $109(18.3)$ & $488(81.7)$ & \multirow[t]{2}{*}{0.550} \\
\hline - Rural & $98(19.7)$ & $400(80.3)$ & \\
\hline \multicolumn{4}{|l|}{ Education of the father: } \\
\hline $\begin{array}{l}\text { - Illiterate/Read \& } \\
\text { write }\end{array}$ & $36(20.7)$ & $138(79.3)$ & \multirow[t]{3}{*}{0.036} \\
\hline - Basic/Secondary & $54(14.6)$ & $315(85.4)$ & \\
\hline - University/Higher & $117(21.2)$ & $435(78.8)$ & \\
\hline \multicolumn{4}{|l|}{$\begin{array}{l}\text { Education of the } \\
\text { mother: }\end{array}$} \\
\hline $\begin{array}{l}\text { - Illiterate/Read \& } \\
\text { write }\end{array}$ & $58(20.9)$ & $219(79.1)$ & \multirow[t]{3}{*}{0.050} \\
\hline - Basic/Secondary & $83(21.4)$ & $304(78.6)$ & \\
\hline - University/Higher & $66(15.3)$ & $365(84.7)$ & \\
\hline \multicolumn{4}{|l|}{$\begin{array}{l}\text { Occupation of the } \\
\text { father: }\end{array}$} \\
\hline - Employee & $132(17.7)$ & $614(82.3)$ & \multirow[t]{4}{*}{0.129} \\
\hline - Worker & $38(18.9)$ & $163(81.1)$ & \\
\hline - Farmer & $24(28.2)$ & $61(71.8)$ & \\
\hline - Died & $13(20.6)$ & $50(79.4)$ & \\
\hline \multicolumn{4}{|l|}{$\begin{array}{l}\text { Occupation of the } \\
\text { mother: }\end{array}$} \\
\hline - Housewife & $66(16.8)$ & $327(83.2)$ & \multirow[t]{2}{*}{0.182} \\
\hline - Employee & $141(20.1)$ & $561(79.9)$ & \\
\hline \multicolumn{4}{|l|}{ Faculty: } \\
\hline - Theoretical & $138(21.7)$ & $498(78.3)$ & \multirow[t]{2}{*}{0.005} \\
\hline - Practical & $69(15.0)$ & $390(85.0)$ & \\
\hline \multicolumn{4}{|l|}{ Academic year: } \\
\hline - 1 st nyear & $27(14.1)$ & $164(85.9)$ & \multirow[t]{5}{*}{0.251} \\
\hline$-2^{2^{\text {nd }}}$ year & $41(17.2)$ & $198(82.8)$ & \\
\hline$-3^{30}$ year & $41(19.6)$ & $168(80.4)$ & \\
\hline - 4th year & $57(21.4)$ & 209 (78.6) & \\
\hline-5 th year & 41 (21.6) & $149(78.4)$ & \\
\hline \multicolumn{4}{|l|}{ Grades of past year: } \\
\hline $\begin{array}{l}\text { - Excellent/Very } \\
\text { Good }\end{array}$ & $30(11.0)$ & $242(89.0)$ & \multirow[t]{3}{*}{$<0.001$} \\
\hline - Good/Pass & $168(21.0)$ & $633(79.0)$ & \\
\hline $\begin{array}{l}\text { - Failed (Repeat the } \\
\text { grade) }\end{array}$ & $9(40.9)$ & $13(59.1)$ & \\
\hline Total & 207 (100.0) & $888(100.0)$ & \\
\hline
\end{tabular}

Table (5) shows that students with better perceived health status (excellent or very good) had significantly lower $(16.7 \%)$ prevalence of smoking than those with bad health status $(25.6 \%)(p<0.001)$. Students with drug abuse and those with previous exposure to violence had significantly higher prevalence of smoking $(85.7 \%$ and $31.8 \%)$ respectively $(p<0.001)$. Students with smoker father or brother or friend and those with pocket money more than 150 Egyptian pounds per month had significantly higher prevalence of smoking $(52 \%, 4.3 \%$ and $43.1 \%)(p<0.001)$.

Table (5): Distribution of smoking among studied students by familial characteristics, (Assiut University, 2017).

\begin{tabular}{|c|c|c|c|}
\hline Characteristics & Smokers & $\begin{array}{c}\text { Non- } \\
\text { smokers }\end{array}$ & $p$-value \\
\hline \multicolumn{4}{|l|}{ Student live with: } \\
\hline - The family & $128(16.2)$ & $663(83.8)$ & $<0.001$ \\
\hline $\begin{array}{l}\text { - Away from the } \\
\text { family }\end{array}$ & $79(26.0)$ & $225(74.0)$ & \\
\hline \multicolumn{4}{|l|}{ Family condition: } \\
\hline $\begin{array}{l}\text { - Both parent } \\
\text { together }\end{array}$ & $152(17.3)$ & $728(82.7)$ & $<0.001$ \\
\hline $\begin{array}{l}\text { - Only one parent is } \\
\text { present }\end{array}$ & $55(25.6)$ & $160(74.4)$ & \\
\hline \multicolumn{4}{|l|}{ Presence of sibling: } \\
\hline - Yes & $195(18.5)$ & $859(81.5)$ & 0.084 \\
\hline - No & $12(29.3)$ & $29(70.7)$ & 0.848 \\
\hline $\begin{array}{l}\text { Mean no. of sibling } \\
( \pm \text { SD })\end{array}$ & $3.5( \pm 2.3)$ & $3.5( \pm 2.1)$ & 0.028 \\
\hline \multicolumn{4}{|l|}{ Marriage: } \\
\hline - Single & $185(18.2)$ & $833(81.8)$ & 0.034 \\
\hline - Engaged & $20(31.7)$ & $43(68.3)$ & \\
\hline - Married & $2(14.3)$ & $12(85.7)$ & \\
\hline \multicolumn{4}{|l|}{ Perceived health } \\
\hline $\begin{array}{l}\text { - Excellent/Very } \\
\text { good }\end{array}$ & $84(16.7)$ & $420(83.3)$ & $<0.001$ \\
\hline - Good & $78(18.8)$ & $337(81.2)$ & \\
\hline - Average (fair)/Bad & $45(25.6)$ & $131(74.4)$ & \\
\hline \multicolumn{4}{|l|}{ Drug abuse: } \\
\hline - Yes & $18(85.7)$ & $3(14.3)$ & $<0.001$ \\
\hline - No & 189 (17.6) & $885(82.4)$ & \\
\hline \multicolumn{4}{|l|}{ Exposure to violence: } \\
\hline - Yes & $54(31.8)$ & $116(68.2)$ & 0.134 \\
\hline - No & $153(16.5)$ & $772(83.5)$ & \\
\hline \multicolumn{4}{|l|}{ Presence of hobbies: } \\
\hline - Yes & $12(13.0)$ & $80(87.0)$ & $<0.001$ \\
\hline - No & $195(19.4)$ & 808 (80.6) & \\
\hline \multicolumn{4}{|l|}{ Smoker father/brother: } \\
\hline - Yes & $133(52.0)$ & $123(48.0)$ & $<0.001$ \\
\hline - No & $74(8.8)$ & $765(91.2)$ & \\
\hline \multicolumn{4}{|l|}{ Smoker friend: } \\
\hline - Yes & $76(41.3)$ & $108(58.7)$ & $<0.001$ \\
\hline - No & $131(14.4)$ & 780 (85.6) & \\
\hline \multicolumn{4}{|l|}{ Pocket money/month: } \\
\hline$-\leq 150$ pounds & $69(8.9)$ & 706 (91.1) & $<0.001$ \\
\hline -> 150 pounds & $138(43.1)$ & $182(56.9)$ & \\
\hline - Mean \pm SD & $117.3 \pm 16.0$ & $108.8 \pm 18.2$ & \\
\hline Total & $207(100.0)$ & 888 (100.0) & \\
\hline
\end{tabular}


Table (6) shows that by logistic regression analysis, the following were associated with smoking among Assiut university students: Male gender $(\mathrm{OR}=13.2)$, students with drug abuse $(\mathrm{OR}=12.1)$, smoker friend $(\mathrm{OR}=11.5)$, smoker father and/or brother $(\mathrm{OR}=10.8)$, pocket money $>150$ pounds per month $(\mathrm{OR}=4.5)$, students who liver away from their families $(\mathrm{OR}=3.7)$, and those who were exposed to violence in the past $(\mathrm{OR}=1.6)$ and bad perceived health status $(\mathrm{OR}=1.5)$.

Table (6): Logistic regression analysis for variables related to smoking among studied students, (Assiut University, 2017).

\begin{tabular}{llc}
\hline Variables & \multicolumn{1}{c}{$\begin{array}{c}\text { Odds ratio } \\
(95 \% \text { CI })\end{array}$} & $\begin{array}{c}p \text { - } \\
\text { value }\end{array}$ \\
\hline Gender (male) & $13.23(6.90-85.52)$ & 0.000 \\
Drug abuse (yes) & $12.11(4.64-73.04)$ & 0.000 \\
Smoker friend (yes) & $11.52(6.34-24.93)$ & 0.000 \\
Smoker father or brother (yes) & $10.81(5.50-22.34)$ & 0.000 \\
Pocket money/month (>150) & $4.52(2.51-9.14)$ & 0.000 \\
Live away from the family & $3.71(1.54-5.54)$ & 0.010 \\
Exposure to violence (yes) & $1.60(1.40-2.34)$ & 0.011 \\
Perceived health status (bad) & $1.53(1.10-2.22)$ & 0.038 \\
Constant & 0.000 & 0.000 \\
\hline
\end{tabular}

R square: 56.2

\section{Discussion}

This study showed that prevalence of smoking among students was $17.1 \%$ and $18.9 \%$ for current and ever smoker. This is consistent with many studies were done in Egypt [3,9,10]. However, our result was higher than reported prevalence by other studies [11-15]. This difference could be denoting that the smoking increases on entering the university with decreased control over youth. On the other hand, our result reported that prevalence of smoking was less than that found some studies $[\mathbf{5 , 8 , 1 6 - 1 9 ]}$. This variation was due to different place and different socio-cultural factors and type of college.

Our result revealed that mean age of initiating cigarette smoking was 16.2 years, this finding is consistent with other studies in other parts of the world $[12,16,18,19]$.

This study shows factors associated with smoking among Assiut university students.

Our result showed that smoking was generally more prevalent among males, a finding that agrees with a large number of studies $[\mathbf{3 , 6 , 8 , 1 6 , 1 8 , 2 0 , 2 1 , 2 2}]$ This is not surprising since males spend more of their free time with their friends and are not supervised by their parents as females [23]. Females certainly smoke less in our society due to familial, social and cultural restrictions, which may accept smoking habit among men.

This study reported that smoker friends was important associated factor of smoking. Nearly all studies documented the same findings $[\mathbf{8 , 1 4 , 1 5}$, $\mathbf{1 6 , 1 8 , 2 3 , 2 4 , 2 5 ]}$. This finding showed the strongest influence of peers' smoking on adolescents' vulnerability and experimentation of smoking. Friends were the main source of the first cigarette revealing the effect of close friends on the behavior of each other.

Our result revealed that father or brothers smoking was associated with adolescents' smoking, this finding was consistent with many studies in other parts of the world $[\mathbf{8}, \mathbf{1 4}, \mathbf{1 5}, \mathbf{1 6 , 2 3 , 2 5}$. Father or brothers Smoking was an important model in promoting and learning smoking behavior.

This result revealed that students who lived away from their families had more prevalence of smoking. This finding agreed with other studies $[18,26]$. Familial care and supervision of adolescents may protect them from smoking [27].

This study result revealed that significantly higher percent of smoking among theoretical faculties' students than practical faculties' students this finding is consistent with other studies $[\mathbf{5 , 6}]$ Theoretical faculties Students may be less aware of smoking dangers or risks, have more time which expose them more to peers' pressure and may be dissatisfied with their study, these factors may be lead them to smoking [18]

In this study as in other studies $[\mathbf{6 , 1 6 , 1 8 , 2 5}$, there was a significant association between smoking and increasing pocket money of students.

The finding of this research also showed that significant association between smoking and drug abuse. This agrees with different studies which reported an association between smoking and drug abuse $[\mathbf{5 , 1 2 , 1 8}$. That's because smoking is constantly the gateway to drug abuse. So, anti-smoking program prevent smoking and drug abuse at the same time.

Also, our result revealed significant relation between smoking and exposure to violence as reported by many studies [28,29]. Moreover, bad perceived health status of the student was significantly associated with smoking. A finding which is reported by other studies [30,31] 


\section{Conclusion and recommendations:}

Smoking is prevalent among Assiut university students. Male students, Drug abuse, smoker friends, father or brothers smoking, Pocket money/ month $>150$ pounds, living away from the family, exposure to violence and bad Perceived health status were significant associated factors of increased prevalence of smoking. Integrated antismoking programs among students in secondary schools and universities are recommended to discourage smoking and raise knowledge of the harmful health impacts of smoking. Supervision of the behavior of student's peers and friends and institutional care for students living away from family is important to prevent smoking. In addition to strategies recommended by WHO to control smoking (MPOWER package) [32] .

\section{References}

1- MATHERS C.D. and LONCAR D.: Projections of global mortality and burden of disease from 2002 to 2030. PLoS Medicine, 3:e442 doi:10.1371/journal.pmed.0030442. PMID:17132052, 2006.

2- MURRAY C.J.L. and LOPEZ A.D.: Alternative projections of mortality and disability by cause 1990-2020: Global Burden of Disease Study. Lancet, 1997, 349:1498-1504 doi:10.1016/S0140-6736(96)07492-2. PMID:9167458, 1997.

3- FOUAD H., EL AWA1 F., ABOU EL NAGA R., EMAM A.H., LABIB S., PALIPUDI K.M., ANDES L.J., ASMA S. and TALLEY B.: Prevalence of tobacco use among adults in Egypt, 2009, IUHPE - Global Health Promotion 1757-759; 23 (2): 38-47, 2013.

4- Centers for Disease Control and prevention [CDC] Fact Sheet: Eastern Mediterranean Region Global Youth Tobacco Survey [GYTS] Egypt, 2009.

5- ABDEL HAMID E.: Drug abuse among Zagazig university students. An epidemiological study. Egyptian Journal of Occupational Medicine, 24: 219-36, 2000.

6- MANDIL A., HUSSEIN A., OMER H., TURKI G. and GABER I.: Characteristics and risk factors of tobacco consumption among university of Sharjah students, 2005. Eastern Med. Health Journal, 3, 2007.

7- MARTINELLI A.M.: An explanatory model of variables influencing health promotion behaviors in smoking and nonsmoking college students. Public Health Nursing, 16 (4): p. 263-269, 1999.

8- EL-GILANY A., BADAWI K.A. and EL-FEDAWY S.: Tobacco smoking among adolescent students in Mansoura, Egypt. Pediatrics, 13 (3): 70-78, 2008.

9- SONG Y., ZHAO L. and PALIPUDI K.M.: Tracking MPOWER in 14 countries: Results from the Global Adult Tobacco Survey, 2008-2010. Glob Health Promot, 23 (Suppl): 24-37, 2016.

10- GIOVINO G.A., MIRZA S.A. and SAMET J.M.: Tobacco use in 3 billion individuals from 16 countries: An analysis of nationally representative cross-sectional household surveys. Lancet, 380: 668-79, 2012.
11-NASSAR H.: The economics of tobacco in Egypt. A new analysis of demand. Health, nutrition and population discussion paper. Washington, DC, Internat. Bank for Reconst and Development/World Bank, 2003.

12-KASSA A. and DEYNO S.: Prevalence and Determinants of Active and Passive Cigarette Smoking among undergraduate students at Hawassa University, Hawassa, Ethiopia. Journal of Trop. Dis. \& Public Health, Volume 2, Issue 4, 1000145, 2014.

13- KEBEDE Y.: Cigarette smoking and khat chewing among university instructors in Ethiopia. East Afr. Med. J., 79: 274-278, 2002.

14- NGAHANE B.H.M., EKOBO H.A. and KUABAN C.: Prevalence and determinants of cigarette smoking among college students: A cross sectional study in Douala, Cameroon. Archives of Public Health, 73: 47, 2015.

15- ISLAM S.M.S. and JOHNSON C.A.: Correlates of Smoking Behavior among Muslim Arab-American Adolescents. Ethnicity \& Health, 8 (4): 319-337, 2003.

16- ALI S.A. and AL-ASADI J.N.: Smoking Behavior and Smoking Determinants Among University Students in Basrah. The Medical Journal of Basrah University, Vol. 28, No. 2, 2010.

17- RACHIOTIS G., BARBOUNI A., KATSIOULIS A., ANTONIADOU F., KOSTIKAS K., MERAKOU K. KOUREA K., KHOURY R.N., TSOUROS A., KREMASTINOU J. and HADJICHRISTODOULOU C.: Prevalence and determinants of current and second hand smoking in Greece: Results from the Global Adult Tobacco Survey (GATS) study. BMJ, 2017.

18- EL-SHARKAWY F.G.: Cigarette Smoking among University Students: Family- related \& Personal risk factors. Journal of American Science, 7 (3): 260-8, 2011.

19- ABU SHOMAR R.T., LUBBAD I.K., EL ANSARI W., AL-KHATIB I.A. and ALHARAZIN H.J.: Smoking, Awareness of Smoking-Associated Health Risks, and Knowledge of National Tobacco Legislation in Gaza, Palestine. Cent. Eur. J. Public Health, 22 (2): 80-89, 2014.

20- IBRAHIM B., SALLAM S., EL-TAWILA S., EL-GIBALY O. and EL-SAHAN F.: Transitions to Adulthood. A National Survey of Egyptian Adolescent. Cairo: Population Council, 1999.

21- HASSAN F., DANDASH K. and WAHEED A.: Tobacco smoking among secondary schools' students in Ismailia, Egypt. Egyptian Journal of Community Medicine, 18 (1): 81-97, 2000.

22- ABDEL-ATY M.A., QAYED M.H. and FADEL K.A.: Health related behaviors among adolescents and youth in Assiut Governorate, Upper Egypt. Bulletin of the High Institute of Public Health, 29 (3): 447, 1999.

23- AL ANSARI B.M.: Sex difference in personality traits in Kuwait. Journal of Gulf States Research, 1996.

24- AZALE T.: Assessment of prevalence and risk factor of chat chewing among in school and out school youth in Gonder town Ethiopia. In. Edited by Medicine DoC. Addis Ababa University, 2007.

25- KHADER Y.S. and ALSADI A.A.: Smoking habits among university students in Jordan: prevalence and associated factors. Eastern Mediterranean Health Journal, Vol. 14, No. 4, 897, 2008. 
26- SHAMSUDDIN K. and ABDUL HARIS M.: Family Influence on Current Smoking Habits Among Secondary School Children in Kota Bharu, Kelantan. Singapore Med. J., 41 (4): 167-71, 2000.

27- VAN DEN BREE M.B., WHITMER M.D. and PICKWORTH W.B.: Predictors of smoking development in a population-based sample of adolescents: A prospective study. J. Adolesc. Health, 35: 172-181, 2004.

28- LELAND A.K., KAWACHI I., BARBEAU E.M. and SUBRAMANIAN S V.: Exposure to domestic violence associated with adult smoking in India: A population based study. BMJ, 16 (6): 378-383, 2007.

29- VERMEIREN R., SCHWAB-STONE M., DEBOUTTE D. and RUCHKIN V.: Violence Exposure and Substance
Use in Adolescents: Findings from Three Countries. Pediatrics, Volume 11. Issue 3, 2003.

30- RIUS C., FERNANDEZ E., SCHIAFFINO A., BORRÀS M. and ARTALEJO F.R.: Self perceived health and smoking in adolescents. Journal of Epidemiology \& Community Health, Volume 58, Issue 8, 2003.

31- SZKLO A.S. and COUTINHO E.S.: Vulnerability and self-perceived health status among light and heavy smokers: The relationship to short-term fear appeal tobacco control messages. Cad Saude Publica, 25 (7): 1534-42, 2009.

32- WHO: WHO report on the global tobacco epidemic, World Health Organization, Geneva, 2008.

\section{التدخين بين طلاب جامعة أسيوط :

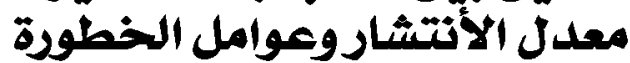

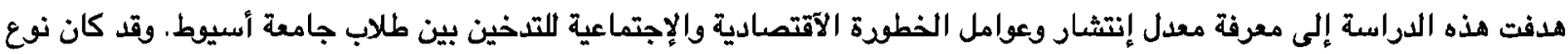

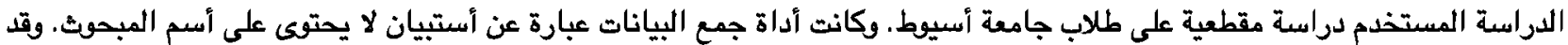

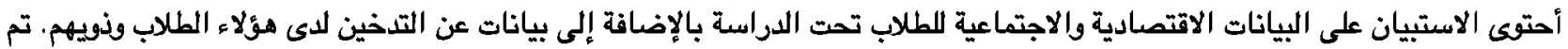

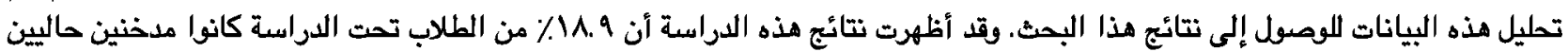

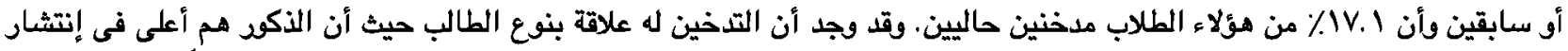

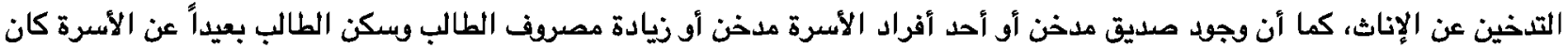

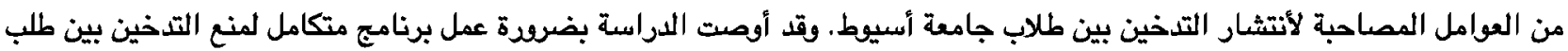

